\title{
Purification and Characterization of Two Acid Proteinases from Dictyostelium discoideum
}

\author{
By MICHAEL J. NORTH* AND ANNE WHYTE \\ Department of Biological Science, University of Stirling, Stirling, FK9 4LA, UK
}

(Received 3 June 1983; revised 3 August 1983)

\begin{abstract}
Two proteinases have been purified from cell extracts of the cellular slime mould Dictyostelium discoideum and have been identified as proteinase $\mathrm{E}$ and proteinase $\mathrm{B}$ by electrophoretic analysis on polyacrylamide gels containing haemoglobin. Both were probably glycoproteins, each consisting of a single polypeptide chain with apparent molecular weights of 58000 (proteinase E) and 30000 (proteinase B) as indicated by SDS-PAGE. A higher molecular weight of 38000 was suggested for proteinase $B$ by gel filtration. On isoelectric focusing multiple forms of proteinase $\mathrm{E}$ were revealed with isoelectric points ranging from 3.05 to 3.35 . There was only a single form of proteinase $\mathrm{B}$ with an isoelectric point at $\mathrm{pH} 3.55$. Both enzymes hydrolysed proteins at low $\mathrm{pH}$ and activated trypsinogen at $\mathrm{pH} 3.5$. Proteinase $\mathrm{B}$ had much lower activity than proteinase $\mathrm{E}$ and required a reducing agent such as DTT for maximum activity. The $\mathrm{pH}$ optimum for activity of proteinase $\mathrm{E}$ towards hide powder azure was $2 \cdot 5$. Proteinase B, but not proteinase $E$, also hydrolysed a number of derivatives of basic amino acids and related peptide derivatives. $N$-Benzoyl- $\alpha$-DL-arginine $\beta$-naphthylamide (Bz-Arg-NNap) was used as substrate during purification, $N$-benzoyl-L-prolyl-L-phenylalanyl-L-arginine $p$-nitroanilide (Bz-Pro-PheArg-Nan) was used for proteinase B characterization. Activity was optimal at pH 6 and was dependent on a reducing agent. Inhibitor studies indicated that proteinase $E$ was probably a pepstatin-insensitive aspartic proteinase which was also inhibited by mercurials through binding to a cysteine residue not involved in the catalytic mechanism. Proteinase $\mathrm{B}$ was inactivated by a range of typical cysteine proteinase inhibitors. Proteinase $B$ may be identical to proteinase I previously purified from $D$. discoideum. Overall the properties of both proteinases were consistent with their being involved in general protein degradation within the lysosomes of D. discoideum.
\end{abstract}

\section{INTRODUCTION}

The proteinases form an important group of enzymes which are now recognized as being involved in a wide range of biological processes and whose role may vary from general protein degradation to subtle proteolytic modification involving the hydrolysis of specific peptide bonds in specific proteins (Holzer \& Heinrich, 1980). In the cellular slime mould Dictyostelium discoideum specific functions have been proposed for proteinases by a number of workers (Fong \& Bonner, 1979; Gustafson \& Thon. 1979; Rossomando et al., 1978), mostly relating to the developmental phase in the life cycle of this organism. However, a number of different proteolytic enzymes have been reported (see North, 1982a) and a detailed analysis of the proteolytic system is essential if roles are to be correctly assigned to individual enzymes and the mechanism and control of proteolysis understood.

Ahbretiations: Bz, benzoyl; Cbz, carbobenzoxy; Tos, tosyl; Suc, succinyl; Nan, 4-nitroanilide; NNap, 2naphthylamide; ONp, 4-nitrophenol: HPA, hide powder azure; DAN, diazoacetyl-DL-norleucine methyl ester: TLCK, $N$ - $x$-p-tosyl-L-lysine chloromethyl ketone; TPCK, L-1-tosylamide-2-phenylethyl chloromethyl ketone: PMSF, phenylmethylsulphonyl fluoride: EPNP, 1,2-epoxy-3-(p-nitrophenoxy)propane: TEMED, $N, N, N^{\prime}, N^{\prime}-$ tetramethylethylenediamine. 
As part of our study of the proteinases of $D$. discoideum we have undertaken the purification and characterization of enzymes active in the acid $\mathrm{pH}$ range. It has been known for some time that $D$. discoideum possesses acid proteinase activity (Sussman \& Sussman, 1969; Wiener \& Ashworth, 1970; Braun et al., 1972; Coukell \& Walker, 1973) but it is only recently that attempts have been made to characterize the enzymes responsible. Fong \& Rutherford (1978) described cathepsin B-like and cathepsin D-like activities, and Gustafson \& Thon (1979) have purified proteinase I which had properties similar to cathepsin B. North \& Harwood (1979) reported that $D$. discoideum possesses at least eight different proteinase species active on haemoglobin at low $\mathrm{pH}$, some of which were cysteine (cathepsin B-like) proteinases (EC 3.4.22.-), the others including the most active proteinase, proteinase $\mathrm{E}$, being characterized solely by their inhibition by mercuric chloride. We have already presented a preliminary report of the purification of proteinase E (North \& Whyte, 1981) but in the present paper we describe an improved purification scheme. A similar scheme has also been used to purify a second proteinase which has been shown by electrophoretic analysis to be the cysteine proteinase $B$. The properties of both proteinase $\mathbf{E}$ and proteinase $\mathbf{B}$ are presented.

\section{METHODS}

Chemicals and reagents. HPA, trypsinogen (type 1), azocasein, haemoglobin (bovine, type II), histone (type II), cytochrome $c$ (type Ila), bovine albumin (fraction V), casein (purified powder), ovalbumin (egg albumin, grade III), Bz-Pro-Phe-Arg-Nan, Bz-Phe-Val-Arg-Nan, Tos-Gly-Pro-Arg-Nan, Bz-Arg-Nan, L-Leu-Nan, L-Lys-Nan, Bz-Arg-NNap, L-Arg-NNap, Cbz-Lys-ONp, DAN, $N$-ethylmaleimide, $N$-bromosuccinimide, iodoacetic acid, iodoacetamide, 1,10-phenanthroline, 8-hydroxyquinoline, $p$-aminophenylmercuric acetate, phenylmercuric acetate, $p$-hydroxymercuribenzoate, $\beta$-phenylpyruvic acid, 4 -bromophenacyl bromide, benzamidine, chloroquine, TLCK, TPCK, hydroxyapatite (type I), sulphosalicylic acid, Fast Garnet GBC, DTT, Schiff's reagent and periodic acid were all purchased from Sigma. Bz-Ile-Glu-Gly-Arg-Nan (S2222) was purchased from KabiVitrum, Ealing, London, U.K., Suc-Ala-Ala-Pro-Leu-Nan from Bachem Feinchemikalien AG, Bubendorf, Switzerland and aminopeptidase M (pancreatic) from Merck. PMSF, mercuric chloride, Coomassie brilliant blue G250, bisacrylamide, SDS (especially pure), DMSO and Folin-Ciocalteu reagent were from BDH. Leupeptin, antipain, chymostatin and pepstatin were all obtained from the Protein Research Foundation, Osaka, Japan. 1,2-Epoxy-3isopropoxypropane, 1,2-epoxy-3-phenoxypropane and EPNP were all purchased from Eastman Kodak. Protein standards for molecular weight determinations were purchased as Combithek Kits from Boehringer. Sephadex G75 Superfine and cyanogen bromide-activated Sepharose 4B were obtained from Pharmacia. Activated Sepharose 4B was also obtained from Sigma. Ampholytes (Ampholines) in the pH 2.5 to 4 and pH 3.5 to 5 range were purchased from LKB, all other ampholytes (Bio-Lytes) and acrylamide were the products of Bio-Rad Laboratories. All other chemicals and reagents were of the highest purity commercially available.

Organism and culture conditions. Dictyostelium discoideum strain AX2 (ATCC 24397) was grown axenically in $700 \mathrm{ml}$ batches of HL5 medium containing glucose as described by Watts \& Ashworth (1970). The myxamoebae were harvested in the late exponential phase of growth (at a density of 5 to $8 \times 10^{6}$ cells $\mathrm{ml}^{-1}$ ) by low speed centrifugation and washed twice with distilled water before preparation of cell extracts.

Enzyme purification. Parallel purification schemes were adopted for proteinase E and proteinase B, with both enzymes purified from the same batch of cells, and with steps 1 to 3 (see below) in common. Proteinase $E$ was assayed throughout using HPA as substrate, proteinase B using Bz-Arg-NNap. At steps 3 to 5 in the proteinase E preparation only fractions with activity on HPA and lacking activity on Bz-Arg-NNap were pooled; for proteinase B fractions containing activity on Bz-Arg-NNap were pooled, taking care to avoid any fractions containing significant levels of activity with HPA in the absence of DTT. Unless otherwise indicated all purification steps were undertaken at $4^{\circ} \mathrm{C}$. Step 1 : Myxamoebae harvested from 10 to 12 cultures were washed and resuspended in $0.02 \mathrm{M}$-sodium acetate/acetic acid buffer, $\mathrm{pH} 5.0$, and treated with $0.1 \%(\mathrm{v} / \mathrm{v})$ Triton X-100 and stirred for $15 \mathrm{~min}$. The sample was centrifuged at $26000 \mathrm{~g}$ for $30 \mathrm{~min}$ and the supernatant retained. Step 2: protein was precipitated with $\left(\mathrm{NH}_{4}\right)_{2} \mathrm{SO}_{4}$, the fraction precipitated at 0 to $50 \%$ saturation was discarded after centrifugation at $26000 \mathrm{~g}$ for $15 \mathrm{~min}$ and that precipitated at 50 to $90 \%$ retained after further centrifugation. The protein

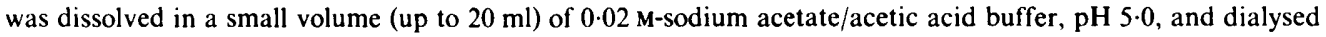
exhaustively against the same buffer overnight. Step 3: the dialysed sample was applied to a column of Sephadex G75 Superfine $(45 \times 4.5 \mathrm{~cm})$ equilibrated with sodium acetate buffer. The column was run at a rate of $35 \mathrm{ml}(10$ fractions) $\mathrm{h}^{-1}$. The appropriate fractions were pooled. Step $4: 2 \mathrm{ml}$ hydroxyapatite [used as supplied by Sigma $25 \%(\mathrm{w} / \mathrm{w})$ in $0.001 \mathrm{M}$-phosphate, $\mathrm{pH} \mathrm{6.8]} \mathrm{was} \mathrm{added} \mathrm{to} \mathrm{the} \mathrm{pooled} \mathrm{fractions} \mathrm{which} \mathrm{were} \mathrm{stirred} \mathrm{gently} \mathrm{for} 30 \mathrm{~min}$. The hydroxyapatite was collected by centrifugation ( $1 \mathrm{~min}$ at $1000 \mathrm{~g}$ in an MSE bench centrifuge), washed twice with $10 \mathrm{ml}$ portions of $0.02 \mathrm{M}$-sodium acetate buffer, $\mathrm{pH} 5 \cdot 0$, and then washed with $2 \mathrm{ml}$ portions of sodium phosphate buffer, pH 6.0, of increasing concentrations $(0.01 \mathrm{M}$ to $0.10 \mathrm{M}$ in $0.0033 \mathrm{M}$ steps for proteinase $\mathrm{E} ; 0.01 \mathrm{M}$ 
to $0.2 \mathrm{M}$ in $0.01 \mathrm{M}$ steps for proteinase $\mathrm{B}$ ). The hydroxyapatite was collected by centrifugation after each washing and the supernatants assayed for enzyme activity. The appropriate active fractions were pooled and dialysed against $0.02 \mathrm{M}$-sodium acetate buffer. Step 5 : a column of haemoglobin-Sepharose $(3 \times 1.5 \mathrm{~cm})$ was prepared from haemoglobin and activated Sepharose 4B (Smith \& Turk, 1974). It was equilibrated with 0.02 M-sodium acetate buffer. The sample was applied to the column and the non-binding material eluted by washing with $50 \mathrm{ml}$ buffer. Proteinase was eluted by the step-wise addition of acetate buffer containing increasing concentrations of $\mathrm{NaCl}$ $(0.1 \mathrm{M}$ to $0.5 \mathrm{M}$ for proteinase $\mathrm{E}: 0.025 \mathrm{M}$ to $0.2 \mathrm{M}$ for proteinase $\mathrm{B})$ in $10 \mathrm{ml}$ portions. The appropriate active fractions were pooled. Proteinase $\mathrm{E}$ preparations were dialysed against distilled water and then either stored frozen or concentrated 100 -fold by freeze-drying. The freeze-dried material was dissolved in $0.02 \mathrm{M}$-acetate buffer. Proteinase B preparations were dialysed against sodium acetate buffer and stored frozen. When more concentrated samples were needed for analysis by electrophoresis or isoelectric focusing, samples were dialysed against water and concentrated by freeze-drying.

Analysis of proteinase samples by electrophoresis and isoelectric focusing. The proteinase band pattern on $12 \%$ ( $w / v)$ acrylamide gels containing denatured haemoglobin was determined as previously (North \& Harwood, 1979) with the modifications described by Kost et al. (1981). Glycoproteins were detected after electrophoresis on $12 \%$ acrylamide gels and staining with periodate-Schiff reagent as described by Zacharius et al. (1969). SDS-PAGE was carried out on $7.5 \%$ acrylamide gels according to the method of Weber et al. (1972).

Analytical isoelectric focusing in thin-layer polyacrylamide plates was carried out using an LKB Multiphor system according to the manufacturer's instructions (Winter et al., 1977) except that $0 \cdot 24 \%$ ( $/ / v$ ) TEMED was added to assist polymerization. The position of the protein bands was determined by staining with Coomassie blue. Proteinase activity was detected by cutting out small sections of gel ( $5 \mathrm{~mm}$ width) from appropriate lanes immediately after isoelectric focusing was complete, and then transferring these to test tubes containing either HPA or Bz-Arg-NNap and buffer for assay using the standard methods. The pH gradient was determined by transferring sections of gel to distilled water and measuring the $\mathrm{pH}$ of the water after equilibration.

All stained gels were scanned at $550 \mathrm{~nm}$ using a Gelman DCD-16 scanner.

Enzyme assays. Unless otherwise indicated all enzyme assays were carried out at $25^{\circ} \mathrm{C}$. Assays involving HPA as substrate were performed using an adaptation of the method described previously (North, 1978). A suspension of HPA $\left(0.5 \mathrm{ml} ; 10 \mathrm{mg} \mathrm{ml}^{-1}\right)$ prepared in water and sonicated for $20 \times 15 \mathrm{~s}$ was added to $0.5 \mathrm{ml}$ buffer. The standard buffer for assays of proteinase $\mathrm{E}$ was Mcllvaine's buffer (citrate/phosphate), $\mathrm{pH} 2 \cdot 5$. The reaction was started by the addition of up to $0.1 \mathrm{ml}$ sample. Shaking, previously used in all assays with HPA, proved to be unnecessary as it did not enhance the rate of release of dye from the substrate presumably because the enzyme can bind tightly to the substrate. After a suitable incubation period (for proteinase E normally $30 \mathrm{~min}$ ) $0.2 \mathrm{ml} 50 \%$ $(w / v)$ TCA was added and the tube left to stand at $4{ }^{\circ} \mathrm{C}$ for $30 \mathrm{~min}$. The insoluble material was removed by centrifugation for $5 \mathrm{~min}$ in an MSE Microcentaur centrifuge and the dye released determined spectrophotometrically at $595 \mathrm{~nm}$. Under these conditions an increase in absorbance of 1.0 was equivalent to the hydrolysis of $3.4 \mathrm{mg} \mathrm{HPA}$. The hydrolysis of other proteins was determined using an identical assay system, i.e. with assay mixes containing $5 \mathrm{mg}$ protein $\mathrm{ml}^{-1}$. After the reaction had been stopped by addition of TCA the amount of acid-soluble material released was determined using the Lowry method. This was related to the amount of protein hydrolysed by determining standard curves with each of the protein substrates.

Trypsinogen activation was determined as follows. Proteinase samples in $0.05 \mathrm{ml}$ were incubated with $0.1 \mathrm{ml}$ $0.01 \mathrm{M}$-sodium acetate/acetic acid buffer, $\mathrm{pH} 3.5$, and $0.05 \mathrm{ml}$ trypsinogen $\left(1 \mathrm{mg} \mathrm{ml}{ }^{-1}\right)$ at $25^{\circ} \mathrm{C}$. With $1.0 \mu \mathrm{g}$ proteinase $\mathrm{E} 30 \mathrm{~min}$ was appropriate. Then $0.5 \mathrm{ml} \mathrm{0.1} \mathrm{M}$-Tris $/ \mathrm{HCl}, \mathrm{pH} 8.0$, and $0.5 \mathrm{ml} \mathrm{HPA}\left(10 \mathrm{mg} \mathrm{ml}^{-1}\right)$ were added and incubation continued at $37^{\circ} \mathrm{C}$. At an appropriate time the reaction was stopped and the rate of dye release determined as above. After deducting values for controls lacking sample and for controls lacking trypsinogen the rate of trypsinogen activation could be calculated. An absorbance increase of 1.0 in $10 \mathrm{~min}$ corresponded to the activation of $0.38 \mathrm{nmol}$ trypsinogen under these conditions.

Activity towards Bz-Arg-NNap was determined by the method of Barrett (1972). A mini-assay which could be carried out in the microtest plate wells was designed for routine determinations of activity during purification. One-tenth of the normal volume for each assay component was used except that Bz-Arg-NNap was added in $0.015 \mathrm{ml}$ DMSO as usual but the stock solution was made up at $1 / 10$ the normal concentration, i.e. at $4 \mathrm{mg} \mathrm{ml}^{-1}$. The presence of enzyme activity in fractions was easily detected from visual observation of the colour in the wells after the reaction had been stopped.

Activity towards most of the peptide nitroanilides and towards Bz-Arg-Nan was determined as follows. The assay mix contained $0.75 \mathrm{ml} 0.1 \mathrm{M}$-sodium phosphate buffer, $\mathrm{pH} 6.0,0.01 \mathrm{ml} 0.1 \mathrm{M}$-DTT, $0.01 \mathrm{ml}$ enzyme sample and $0.05 \mathrm{ml} 1 \mathrm{~mm}$-substrate (added last). Bz-lle-Glu-Gly-Arg-Nan and Bz-Arg-Nan were dissolved initially in dimethylformamide at a concentration of $20 \mathrm{~mm}$ and then diluted in water; all other substrates were dissolved directly in water. In some assays aminopeptidase $\mathrm{M}(4 \mu \mathrm{g}$ per assay tube) was included. The activity was determined from the rate of release of 4-nitroaniline, measured spectrophotometrically at $405 \mathrm{~nm}$ with readings taken every 20 to $30 \mathrm{~min}$. Activity towards Suc-Ala-Ala-Pro-Leu-Nan was assayed identically except that $0 \cdot 1 \mathrm{M}$ Tris/ $/ \mathrm{HCl}, \mathrm{pH} 8 \cdot 0$, was used as the buffer. 
Aminopeptidase activity was tested with L-Leu-Nan and L-Lys-Nan using the method of Firtel \& Brackenbury (1972) except that L-Lys-Nan stock solutions were prepared in water and the assay with the latter was carried out at pH 6.0. Assays using L-Leu-NNap and L-Arg-NNap as substrates were carried out by the same method as that used with Bz-Arg-NNap (Barrett, 1972) except that the assay with L-Leu-NNap was carried out at pH 7.0.

The assay involving Cbz-Lys-ONp as substrate was carried out according to Gustafson \& Thon (1979) except that the $\mathrm{pH}$ was $6 \cdot 0$.

The enzyme activities are given in units of $\mathrm{mg}$ protein hydrolysed $\mathrm{min}^{-1}$ (HPA and other proteins), $\mathrm{nmol}$ trypsinogen activated $\mathrm{min}^{-1}$ or $\mathrm{nmol}$ product released $\mathrm{min}^{-1}$ (derivatives of 4-nitroaniline, 2-naphthylamine or 4nitrophenol) and all specific activities are given in units of enzyme activity (mg protein) ${ }^{-1}$. Protein was estimated by the Coomassie brilliant blue method (Sedmak \& Grossberg, 1977) using bovine albumin as standard.

Treatment with proteinase inhibitors. The standard procedure for examining the effect of potential inhibitors involved determining the activity remaining after preincubation of proteinase samples with inhibitors for $1 \mathrm{~h}$ at room temperature. Unless otherwise indicated the inhibitor concentration during preincubation was $1 \mathrm{~mm}$. When enzyme assays were carried out there was a 10 -fold dilution of inhibitor. Stock solutions of inhibitor were prepared at 10 times the required concentration in methanol (chymostatin, pepstatin, TPCK and PMSF), DMSO ( $p$ bromophenacyl bromide) or water (all other inhibitors). Organomercurials were sometimes prepared at twice the required concentration. Normally preincubation was carried out at $\mathrm{pH} 6 \cdot 0$ (in $0 \cdot 1 \mathrm{M}$-sodium phosphate), although $\mathrm{N}$-bromosuccinimide was always tested at $\mathrm{pH} 7 \cdot 5$. With certain of the inhibitors the standard procedure was not used. The effect of DAN was tested after $1 \mathrm{~h}$ preincubation at $\mathrm{pH} 5.0,15^{\circ} \mathrm{C}$ (North, 1978). The epoxypropane derivatives were added directly to proteinase samples in buffer which was normally $0.1 \mathrm{M}$-glycine $/ \mathrm{HCl}, \mathrm{pH} 3.0$, to give a saturated solution (approximately $4 \mathrm{mg} \mathrm{ml}^{-1}$ ). The activity remaining was determined after samples had been shaken for $72 \mathrm{~h}$ at room temperature. Chloroquine and $\mathrm{HgCl}_{2}$ were tested without preincubation and were added directly to the assay system.

\section{RESULTS}

\section{Enzyme purification}

Proteinase $\mathrm{E}$ is the major proteinase detected when cell extracts of $D$. discoideum are analysed by electrophoresis on polyacrylamide gels containing haemoglobin (North \& Harwood, 1979) and is also likely to be the major contributor to the proteinase activity detected at low $\mathrm{pH}$ with HPA as substrate. The purification scheme therefore involved procedures in which the activity on HPA was retained and analysis on haemoglobin gels was used to check that it was due to proteinase E, an approach used in previous purification attempts (North \& Whyte, 1981). A new purification scheme was necessary because the earlier preparations of proteinase $E$ were found to contain traces of activity on Bz-Arg-NNap which was not expected to be a substrate for this enzyme. Particular attention was paid to the removal of any activity on Bz-Arg-NNap and preparations ultimately had undetectable levels of activity. However a parallel purification scheme was found to be suitable for the purification of one of the enzymes responsible for the hydrolysis of $\mathrm{Bz}-\mathrm{Arg}-\mathrm{NN}$ ap and in this case care was taken to remove all traces of proteinase $\mathrm{E}$ activity which was determined using HPA as substrate in the absence of DTT. A summary of the purification schemes is given in Table 1. Over 10 successful preparations of both enzymes have been made. For proteinase $\mathrm{E}$ the mean specific activity was 23 units (mg protein) ${ }^{-1}$ with yields of 3 to $6 \%$ of the total activity towards HPA, and for proteinase B the mean specific activity was 1090 units (mg protein) ${ }^{-1}$ with yields of 6 to $10 \%$ of the total activity towards BzArg-NNap.

For both proteinases the first steps involved precipitation of protein by $\left(\mathrm{NH}_{4}\right)_{2} \mathrm{SO}_{4}$ at 50 to $90 \%$ saturation from cell lysates prepared by treatment with Triton X-100. For both activities a proportion was precipitated at lower $\left(\mathrm{NH}_{4}\right)_{2} \mathrm{SO}_{4}$ concentrations. Indeed the yield of activity towards HPA was not high but the step was retained in the proteinase $\mathrm{E}$ purification as its inclusion improved the recovery of activity at later stages. To separate the two activities samples were applied to a column of Sephadex G75 Superfine (Fig 1). Most activity towards HPA eluted as a single peak corresponding to a molecular weight of 58000 . The activity towards $\mathrm{Bz}-\mathrm{Arg}-$ NNap appeared in later fractions which corresponded to a molecular weight of 38000 . Further purification of the enzymes from one another depended on differences in their affinities for hydroxyapatite and haemoglobin-Sepharose.

Both enzymes bound to hydroxyapatite with optimal binding at pH 5 and no unbound activity was detectable. The enzymes were released by the step-wise addition of sodium phosphate 
Table 1. Proteinase purification

\begin{tabular}{|c|c|c|c|c|c|}
\hline \multirow[b]{2}{*}{ Fraction } & \multirow[b]{2}{*}{$\begin{array}{l}\text { Protein } \\
\text { (mg) }\end{array}$} & \multicolumn{4}{|c|}{ Enzyme parameters } \\
\hline & & $\begin{array}{l}\text { Total activity } \\
\text { (units) }\end{array}$ & $\begin{array}{c}\text { Specific activity } \\
{\left.\text { [units (mg protein })^{-1}\right]}^{\text {] }}\end{array}$ & $\begin{array}{l}\text { Purification } \\
\text { factor }\end{array}$ & $\begin{array}{c}\text { Yield } \\
(\%)\end{array}$ \\
\hline \multicolumn{6}{|l|}{ Proteinase $\mathrm{E}^{*}$} \\
\hline Crude extract & 544 & 126 & $0 \cdot 23$ & $(1 \cdot 00)$ & 100 \\
\hline$\left(\mathrm{NH}_{4}\right)_{2} \mathrm{SO}_{4}(50$ to $90 \%)$ & 145 & $38 \cdot 7$ & 0.27 & $1 \cdot 17$ & 31 \\
\hline Sephadex G75 Superfine & $3 \cdot 01$ & $27 \cdot 6$ & $9 \cdot 16$ & $39 \cdot 8$ & 22 \\
\hline Hydroxyapatite & 1.06 & $12 \cdot 6$ & $12 \cdot 0$ & $52 \cdot 2$ & 10 \\
\hline Haemoglobin-Sepharose & $0 \cdot 26$ & $7 \cdot 21$ & $24 \cdot 6$ & 107 & $5 \cdot 7$ \\
\hline \multicolumn{6}{|l|}{ Proteinase $\mathrm{B} \dagger$} \\
\hline Crude extract & 580 & 2132 & 3.67 & $(1.00)$ & 100 \\
\hline$\left(\mathrm{NH}_{4}\right)_{2} \mathrm{SO}_{4}(50$ to $90 \%)$ & 22 & 1187 & $54 \cdot 0$ & $14 \cdot 7$ & $55 \cdot 7$ \\
\hline Sephadex G75 Superfine & $1 \cdot 12$ & 1273 & 1140 & 310 & $59 \cdot 7$ \\
\hline Hydroxyapatite & 0.41 & 608 & 1480 & 404 & $28 \cdot 5$ \\
\hline \multirow[t]{2}{*}{ Haemoglobin-Sepharose } & $0 \cdot 17$ & 197 & 1160 & 316 & $9 \cdot 2$ \\
\hline & & $\begin{array}{l}\text { d with HP } \\
\text { d with Bz- }\end{array}$ & $\operatorname{san} 2$ & & \\
\hline
\end{tabular}

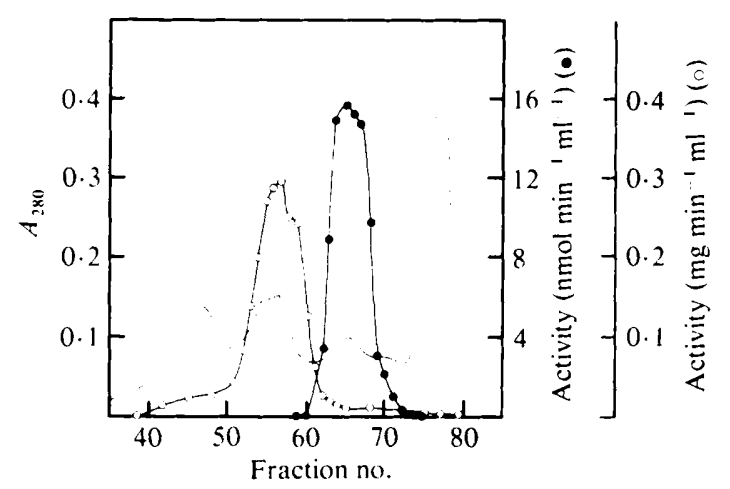

Fig. 1. Proteinase separation by gel filtration. A sample of protein precipitated by $\left(\mathrm{NH}_{4}\right)_{2} \mathrm{SO}_{4}$ at 50 to $90^{\circ}$ o saturation was applied to a column of Sephadex G75 Superfine. Activity was determined using HPA $(O)$ and Bz-Arg-NNap (O) as substrates. - $A_{280}$.

buffer. In proteinase E preparations most of the activity towards HPA was released as a single peak in the 0.025 to $0.06 \mathrm{M}$ range. Activity towards Bz-Arg-NNap was more tightly bound and in proteinase $B$ preparations a single peak of activity was released in the 0.05 to $0.15 \mathrm{M}$ range. On the haemoglobin-Sepharose columns proteinase $E$ had the greater affinity. Both enzymes were released by $\mathrm{NaCl}$. The activity towards HPA in proteinase $\mathrm{E}$ preparations was eluted as a single peak by 0.1 to $0.3 \mathrm{M}-\mathrm{NaCl}$, the activity towards $\mathrm{Bz}-\mathrm{Arg}-\mathrm{NN}$ ap in proteinase B preparations as a single peak by 0 to $0.05 \mathrm{M}-\mathrm{NaCl}$. Other affinity media have also been tested. As expected from their sensitivity to $\mathrm{HgCl}_{2}$ (North \& Harwood, 1979) both proteinase $\mathrm{B}$ and proteinase $\mathrm{E}$ bound to organomercurial-Sepharose (Barrett, 1973) but the method did not allow separation of the two types of enzyme. Whilst for both enzymes steps 4 and 5 resulted in a decreased yield with only a small increase in specific activity (Table 1) they did allow the removal of all traces of unwanted proteolytic activities from the preparations. Samples of proteinase E obtained after affinity chromatography were normally concentrated by freeze-drying after removal of the $\mathrm{NaCl}$ by dialysis against water. This treatment had no effect on the activity of the preparations. Proteinase B preparations were only freeze-dried prior to electrophoretic analysis. 


\section{Electrophoretic analysis}

For both enzymes only one band of proteinase activity was detected when enzyme preparations were analysed on gels containing haemoglobin. The bands developed at both $\mathrm{pH} 2$ and $\mathrm{pH} 4$ but for proteinase B 1 mM-DTT was essential for activity. The positions of the bands were characteristic of the two proteinases (relative mobilities of 0.45 and 0.76 for proteinases $E$ and $B$, respectively). Indeed only when the purified preparation was subjected to this analysis did the identity of the enzyme responsible for the activity towards Bz-Arg-NNap become known.

Both enzymes gave positive reactions with periodate-Schiff reagent with prominant bands at the same positions as the corresponding bands in haemoglobin gels when samples were run on identical gels lacking haemoglobin. Thus both proteinases are presumably glycoproteins. In proteinase $\mathrm{E}$ preparations a minor slower band was sometimes observed. This minor band was also sometimes encountered when samples were analysed by SDS-PAGE and stained with Coomassie blue. The major band was at a position corresponding to an apparent molecular weight of $58000 \pm 500$, in agreement with the elution position on gel filtration (Fig. 1). The minor band had an apparent molecular weight of 71000 . It is possible that it corresponded to proteinase $E^{\prime}$, an enzyme that is sometimes detected when cell extracts are analysed on haemoglobin gels (North \& Harwood, 1979). Apart from their separation on haemoglobin gels proteinases $E$ and $E^{\prime}$ seem to have similar properties and it has proved difficult to eliminate proteinase $E^{\prime}$ from every preparation. Occasionally bands corresponding to polypeptides of lower apparent molecular weights, principally 32000 and 23000 , were detected. These may be due to autolysis and analogous to products observed in bovine spleen cathepsin D (Lah \& Turk, 1982). Proteinase B preparations normally contained only one polypeptide detected with Coomassie blue after SDS-PAGE. It corresponded to an apparent molecular weight of $30000 \pm 1500$. Occasionally two minor bands with apparent molecular weights of 20000 and 10000 were detected.

\section{Isoelectric focusing}

When analysed by isoelectric focusing using a broad $\mathrm{pH}$ range ( 3.5 to 9.5 ) preparations of both proteinases were found only to contain proteins which migrated to the anode. Using a narrower range of $\mathrm{pH}(2.5$ to 4.2$)$ proteinase $\mathrm{E}$ preparations were found to contain multiple protein species with isoelectric points ranging from $\mathrm{pH} 3.05$ to $\mathrm{pH} 3.35$ and the major species had its isoelectric point at pH 3.15 (Fig. 2a). Proteinase B preparations had a single band of protein with an isoelectric point at pH 3.55 (Fig. $2 b$ ). For both proteinases, enzyme activity was detected in those sections of the gel corresponding to the protein bands. A band of proteinase activity in those sections was also seen with proteinase $\mathrm{E}$ preparations by staining with azocasein using a method similar to that of Ansari \& Stevens (1983).

\section{Activity towards proteins}

As demonstrated by their ability to form bands on haemoglobin gels both enzymes possessed proteinase activity. Proteinase $\mathrm{E}$ was active towards a range of proteins (Table 2) and in all cases the activity was greater at $\mathrm{pH} 2.5$ than at $\mathrm{pH} 3.5$ and was barely detectable at $\mathrm{pH} 6$. The activity was unaffected by reducing agents such as DTT. In contrast the proteinase activity of proteinase B was greatly enhanced by DTT (Fig. 3) but even in the presence of $1 \mathrm{~mm}$-DTT it was less active than proteinase $\mathrm{E}$ (Table 2). The $\mathrm{pH}$-dependence of the activity of both enzymes towards HPA is shown in Fig. 3. Both activities were highest at acid pH. Many acid proteinases from eukaryotic micro-organisms are able to activate trypsinogen at low pH (North, 1982a). This trypsinogen kinase activity was possessed by both proteinases with optimal rates of activation when proteinase and trypsinogen were incubated at $\mathrm{pH} 3.0$ to 3.5 . At $\mathrm{pH} 3.5$ the rates of activation were 7.80 and $0.16 \mathrm{nmol}$ trypsinogen activated $\min ^{-1}(\mathrm{mg} \text { protein })^{-1}$ for proteinase E and proteinase B, respectively. DTT was essential for the proteinase B activity. 

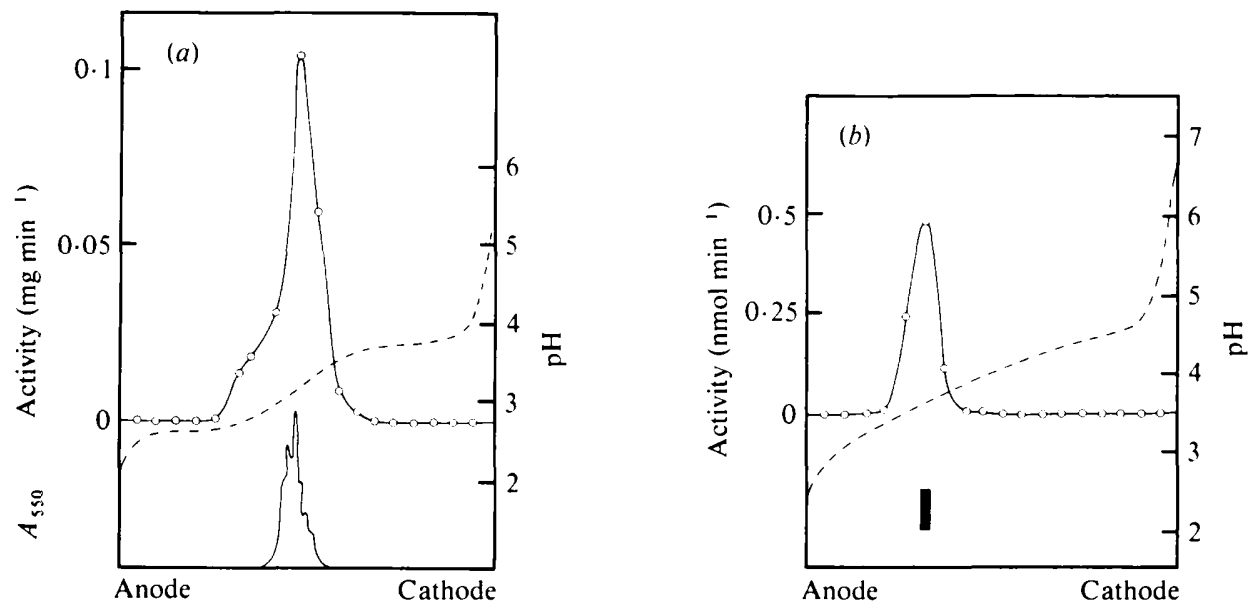

Fig. 2. Isoelectric focusing. Samples of $(a)$ proteinase E containing $15 \mu \mathrm{g}$ protein and $(b)$ proteinase B containing $10 \mu \mathrm{g}$ protein were subjected to isoelectric focusing in the $\mathrm{pH} 2 \cdot 5$ to 4.2 range (dashed line). For proteinase $\mathrm{E}$ the position of bands staining with Coomassie blue is indicated by the densitometric scan at the bottom of the Figure $(a)$. For proteinase B the position of the single staining band is shown $(b)$. Enzyme activity $(O)$ was determined using $(a)$ HPA or $(b)$ Bz-Arg-NNap as substrate after transferring $5 \mathrm{~mm}$ length sections of gel to a standard assay mix.

\section{Table 2. Activity of purified proteinases on various substrates}

The concentrations of the substrates were $5 \mathrm{mg} \mathrm{ml}^{-1}$ (proteins) and $0.043 \mathrm{~mm}$ (amino acid and peptide derivatives) except when Bz-Arg-NNap and Cbz-Lys-ONp were used with the standard method given in Methods. All assays were carried out in the presence of $1 \mathrm{mM}$-DTT except for the standard assays with Bz-Arg-NNap and Cbz-Lys-ONp and, for proteinase $E$ only, those with proteins as substrates. Standard assay conditions: $2.2 \mathrm{mM}-\mathrm{Bz}-\mathrm{Arg}-\mathrm{NN}$ ap with $2 \mathrm{~mm}$-cysteine and $0.1 \mathrm{~mm}$-EDTA; $0.5 \mathrm{~mm}$ Cbz-Lys-ONp with $5.5 \mathrm{~mm}$-DTT. Each value is the average from two determinations.

\begin{tabular}{|c|c|c|c|}
\hline \multirow[b]{2}{*}{ Substrate } & \multirow[b]{2}{*}{$\mathrm{pH}$} & \multicolumn{2}{|c|}{$\begin{array}{c}\text { Specific activity } \\
\text { [units }\left(\mathrm{mg} \text { protein) }^{-1} \text { ] }\right.\end{array}$} \\
\hline & & Proteinase $\mathrm{E}$ & Proteinase $\mathbf{B}$ \\
\hline \multicolumn{4}{|l|}{ Proteins } \\
\hline Hide powder azure & $2 \cdot 5$ & $24 \cdot 6$ & 1.47 \\
\hline Cytochrome $c$ & $2 \cdot 5$ & $18 \cdot 0$ & - \\
\hline Histone & $2 \cdot 5$ & $16 \cdot 2$ & $2 \cdot 31$ \\
\hline Casein & $2 \cdot 5$ & $7 \cdot 40$ & $4 \cdot 11$ \\
\hline Haemoglobin & $2 \cdot 5$ & $6 \cdot 33$ & - \\
\hline Bovine albumin & $2 \cdot 5$ & $5 \cdot 58$ & - \\
\hline Ovalbumin & $2 \cdot 5$ & $3 \cdot 48$ & - \\
\hline \multicolumn{4}{|c|}{ Amino acid and peptide derivatives } \\
\hline Bz-Pro-Phe-Arg-Nan & $6 \cdot 0$ & ND & 820 \\
\hline Bz-Phe-Val-Arg-Nan & $6 \cdot 0$ & ND & 227 \\
\hline Tos-Gly-Pro-Arg-Nan & $6 \cdot 0$ & ND & 167 \\
\hline Bz-Val-Gly-Arg-Nan & $6 \cdot 0$ & ND & $71 \cdot 4$ \\
\hline Bz-Val-Gly-Arg-Nan & $6 \cdot 0$ & ND & $347^{*}$ \\
\hline Bz-Ile-Glu-Gly-Arg-Nan & $6 \cdot 0$ & ND & $13 \cdot 9$ \\
\hline Bz-Arg-Nan & $6 \cdot 0$ & ND & $5 \cdot 5$ \\
\hline Bz-Arg-NNap & $6 \cdot 0$ & ND & $1400+$ \\
\hline Cbz-Lys-ONp & $6 \cdot 0$ & ND & $13100 \dagger$ \\
\hline
\end{tabular}

- , Not determined.

ND, Not detectable. Limits of detection for nitroaniline derivatives, Bz-Arg-NNap and Cbz-Lys-ONp were $0 \cdot 1$, 0.003 and $10 \mathrm{nmol}$ product released $\min ^{-1}$ (mg protein $)^{-1}$, respectively.

* Assayed in the presence of aminopeptidase $M\left(4.8 \mu \mathrm{g} \mathrm{ml}^{-1}\right)$.

$\uparrow$ Standard assay conditions. 

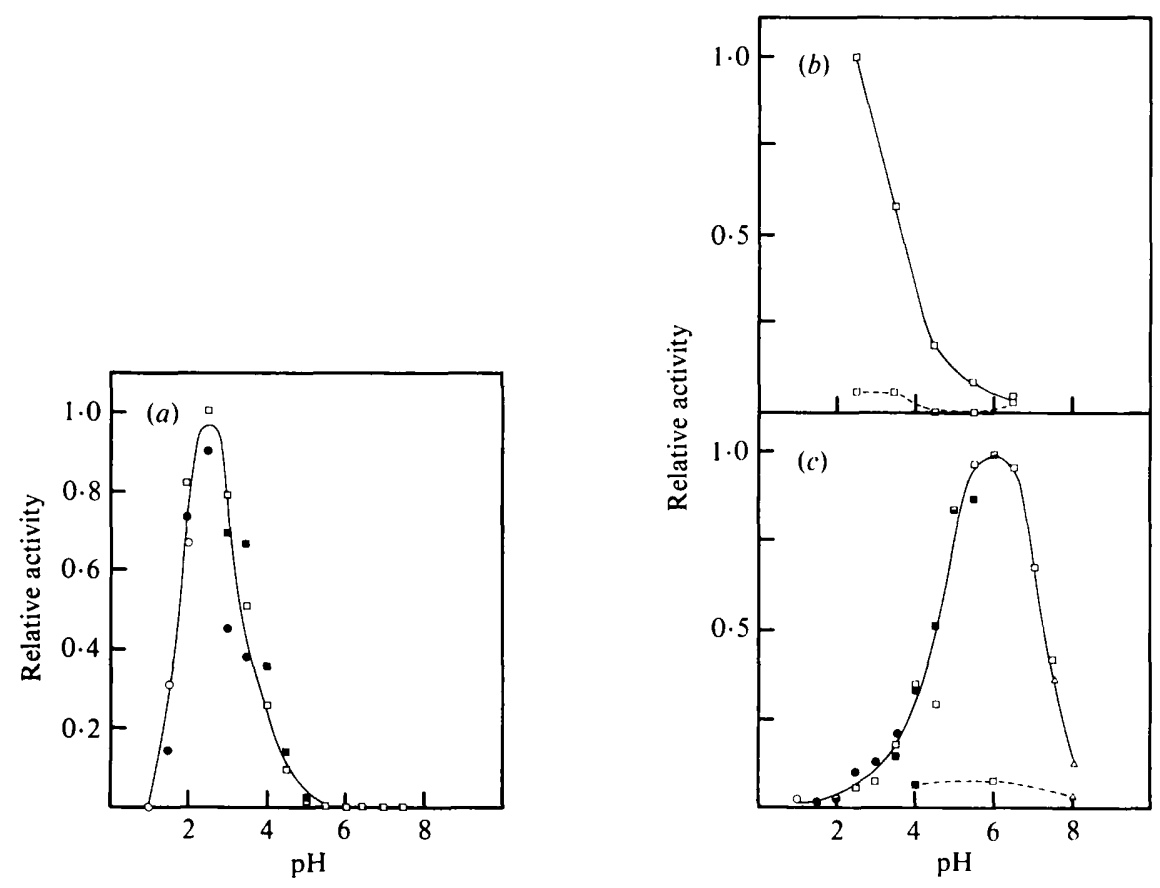

Fig. 3. pH-dependence of proteinase activity $(a)$ Proteinase E; $(b, c)$ proteinase B. Activity was measured using HPA $(a, b)$ or Bz-Pro-Phe-Arg-Nan $(c)$; for proteinase E no DTT was included in the assay but proteinase $\mathrm{B}$ was assayed in the presence (continuous line) and absence (broken line) of $1 \mathrm{mM}$ DTT. Buffers: $0 \cdot 1 \mathrm{M}-\mathrm{KCl} / \mathrm{HCl}(\mathrm{O}) ; 0.1 \mathrm{M}$-glycine/ $\mathrm{HCl}(\mathrm{O})$; McIlvaine's buffer (citrate/phosphate) $(\square) ; 0 \cdot 1 \mathrm{M}$-sodium acetate/acetic acid $(\square) ; 0 \cdot 1 \mathrm{M}-\mathrm{Tris} / \mathrm{HCl}(\triangle)$. The activity is given relative to the maximum activity of 27.1 units (mg protein) ${ }^{-1}$ (proteinase E, HPA), 1.50 units (mg protein) ${ }^{-1}$ (proteinase B, HPA) and 1180 units (mg protein) ${ }^{-1}$ (proteinase B, Bz-Pro-Phe-Arg-Nan).

\section{Activity towards low molecular weight substrates}

Proteolytic activities in cell extracts of $D$. discoideum have been detected using a number of amino acid and peptide derivatives (Fong \& Rutherford, 1978; Gustafson \& Thon, 1979; North, $1982 b$; Firtel \& Brackenbury, 1972). Proteinase $\mathrm{E}$ had no detectable activity towards any of these (Table 2). Proteinase B, however, was active towards a number of them (Table 2), and the information obtained not only provided some understanding of the specificity of the catalytic process but also suggested an alternative substrate to Bz-Arg-NNap. Although the rapid hydrolysis of the latter substrate made it suitable during the purification its use does have a number of disadvantages including the hazardous nature of the reaction product, 2-naphthylamine, which is probably carcinogenic, and the need for a coupling reagent, Fast Garnet GBC, to reveal activity which complicates enzyme assays. Fong \& Rutherford (1978) used Bz-ArgNan to assay cathepsin B-like activity but only low activity was reported and this was a poor substrate for proteinase B (Table 2). Much higher activities were found with peptide nitroanilides and the best substrate was Bz-Pro-Phe-Arg-Nan which was hydrolysed 150-fold faster than Bz-Arg-Nan and at a rate which compared well with $\mathrm{Bz}-\mathrm{Arg}-\mathrm{NNap}$. Indeed when substrate concentrations were the same Bz-Arg-NNap was the poorer substrate. Other substrates with arginine residues at the $P_{1}$ position (as defined by Schechter \& Berger, 1967) were also hydrolysed with the rate dependent on the nature of the other residues in the substrate. Proteinase B was also active towards Cbz-Lys-ONp, the substrate used by Gustafson \& Thon (1979) to assay proteinase I. Indeed, this substrate was hydrolysed more rapidly than all others tested even with conditions comparable to those used for the peptide nitroanilides. However we have experienced some difficulties with this substrate using assay conditions based on those of 
Gustafson \& Thon (1979) since the substrate is unstable and the assay is only suitable when samples have high levels of activity. The assay was improved if concentrations of substrate and DTT were lowered to $0.043 \mathrm{mM}$ and $1 \mathrm{mM}$, respectively. In cell extracts, additional activities were detected when peptide nitroanilides were used in combination with aminopeptidase $\mathbf{M}$ (North, 1982b). There was an increase in the rate of nitroaniline release from Bz-Val-Gly-ArgNan when aminopeptidase $M$ was added to the assay system. This was not observed with any other substrate.

Neither proteinase had any activity towards the unblocked amino acid derivatives L-LysNan, L-Leu-Nan, L-Leu-NNap and L-Arg-NNap which are hydrolysed by aminopeptidases of D. discoideum (Firtel \& Brackenbury, 1972; M. J. North, unpublished observations). The assays would have allowed the detection of activities as low as 0.3 to $1 \cdot 1$ units (mg protein) ${ }^{-1}$. The lack of activity demonstrated the importance of the $\mathrm{N}$-terminal blocking group in substrates of proteinase $B$ which were otherwise identical to the aminopeptidase substrates. Neither of the two proteinases was active on Suc-Ala-Ala-Pro-Leu-Nan which has been used to demonstrate a neutral cytosolic activity (North, 1982b).

For further characterization, proteinase B was assayed using Bz-Pro-Phe-Arg-Nan. The activity, like that towards proteins, was considerably enhanced by reducing agents, the best of these being DTT (Fig. 3c) and cysteine. The activity was optimal at pH 6.0 (Fig. $3 c$ ) which contrasted with the pH-dependence of the activity towards HPA (Fig. $3 b$ ).

\section{Stability and temperature dependence}

Proteinase E activity was stable for at least $24 \mathrm{~h}$ at $25^{\circ} \mathrm{C}$ in the whole of the $\mathrm{pH}$ range from $\mathrm{pH} 2$ to 9 . Proteinase B activity, however, decreased by $50 \%$ during $1 \mathrm{~h}$ incubation at $\mathrm{pH} 6$. At lower and at higher $\mathrm{pH}$ values the extent of inactivation was even greater, although at all $\mathrm{pH}$ values at least some activity was retained after $1 \mathrm{~h}$ at $25^{\circ} \mathrm{C}$. DTT $(1 \mathrm{mM})$ stabilized the activity at $\mathrm{pH}$ 6. Both proteinases were active at temperatures up to $50^{\circ} \mathrm{C}$.

\section{Proteinase inhibitors}

Proteinase E was inhibited severely (i.e. by over $85 \%$ ) by two agents, DAN and EPNP, which inhibit most aspartic proteinases including cathepsin D and pepsin (Barrett \& McDonald, 1980). Inactivation by DAN was dependent on the presence of cupric ions. The finding that EPNP would inactivate proteinase $E$ contrasted with an earlier observation (North, 1978). However it was found that a lower $\mathrm{pH}, \mathrm{pH} 3$, was necessary for successful inactivation. Similar effects to that of EPNP were observed with other epoxypropane derivatives. Surprisingly pepstatin, another aspartic proteinase inhibitor, had no effect on proteinase $E$ activity. This was so regardless of the solvent used for preparing the stock solution (water, methanol, ethanol, DMSO) or of the $\mathrm{pH}$ at which preincubation of enzyme with inhibitor was carried out ( $\mathrm{pH} 2$ to 6). The concentration of pepstatin, $100 \mu \mathrm{g} \mathrm{ml}^{-1}$, was well in excess of that required to inhibit most aspartic proteinases. The pepsin inhibitor $p$-bromophenacyl bromide had no effect either. In agreement with earlier findings (North \& Harwood, 1979) proteinase E was severely inhibited by $\mathrm{HgCl}_{2}$. It was also inactivated by phenylmercuric acetate, aminophenylmercuric acetate and $p$-hydroxymercuribenzoate, an effect that was $\mathrm{pH}$-dependent, with optimal inactivation at $\mathrm{pH} 6$, and could be reversed by carrying out assays in the presence of DTT. $p$-Aminophenylmercuric acetate was also shown to inhibit trypsinogen activation and also prevented the inactivation of proteinase $\mathrm{E}$ by DAN. Trypsinogen activation was also shown to be blocked by DAN and $\mathrm{HgCl}_{2}$. Proteinase $\mathrm{E}$ activity was not affected by a wide range of cysteine proteinase inhibitors (except for the mercurials), the serine proteinase inhibitor PMSF and the metalloproteinase inhibitors EDTA, phenanthroline and hydroxyquinoline. It was, however, severely inhibited by $N$-bromosuccinimide and, as reported previously (North et al., 1982), by $50 \mathrm{~mm}$ chloroquine.

The sensitivity of proteinase B to inhibitors indicated that it was a different type of proteinase from proteinase E. Because of the requirement for DTT in the assay the effects of mercurials were not tested although it had been shown previously (North \& Harwood, 1979) that proteinase 
B is severely inhibited by $\mathrm{HgCl}_{2}$. It was also severely inhibited by a number of other agents which inactivated cysteine proteinases (Barrett, 1977; Barrett \& McDonald, 1980) such as antipain $\left(10 \mu \mathrm{g} \mathrm{ml}^{-1}\right)$, leupeptin $\left(10 \mu \mathrm{g} \mathrm{ml}^{-1}\right)$, chymostatin $\left(100 \mu \mathrm{g} \mathrm{ml}^{-1}\right)$, iodoacetic acid, iodoacetamide, TLCK and TPCK, although $N$-ethylmaleimide had no effect. DAN, often considered as a specific aspartic proteinase inhibitor, but reported by Barrett (1977) also to inhibit cysteine proteinases, did inactivate proteinase B and the inactivation was not completely dependent on cupric ions. Phenanthroline which inhibits a number of cysteine proteinases from protozoa (North, 1982a) was also a severe inhibitor as was $N$-bromosuccinimide. In agreement with previous reports (Fong \& Bonner, 1979; North et al., 1982) proteinase B activity was also blocked by $50 \mathrm{~mm}$-chloroquine. Pepstatin $\left(100 \mu \mathrm{g} \mathrm{ml}^{-1}\right)$, PMSF, EDTA and hydroxyquinoline did not have any effect. A moderate inhibitory effect ( $27 \%$ reduction in activity) was observed with $10 \mathrm{~mm}$-benzamidine which is of interest because this has been used as a protective agent in the preparation of cyclic AMP binding proteins from D. discoideum (Leichtling et al., 1982).

\section{DISCUSSION}

Prior to the work reported in this paper only one proteinase had been purified from $D$. discoideum, the cysteine proteinase I described by Gustafson \& Thon (1979). From the properties described here it is clear that proteinase B may be the same or a similar enzyme, but proteinase $E$ represents a different type of enzyme. In a number of respects the latter resembled acid proteinases found in fungi, most of which are considered to be aspartic proteinases (EC 3.4.23.-) (North, 1982a). It hydrolysed a range of proteins at acid $\mathrm{pH}$, activated trypsinogen and was inactivated by DAN and EPNP. However a major difference between this and most other proteinases active at low $\mathrm{pH}$ was that it was not inhibited by pepstatin. In this respect our observations differ from those of Fong \& Rutherford (1978) and Fong \& Bonner (1979) who reported a cathepsin D-like activity in $D$. discoideum which was pepstatin-sensitive. The finding that mercurials inhibited proteinase $E$ does not indicate that the enzyme had a cysteine residue involved directly in the catalytic mechanism. This was ruled out by the lack of effect of agents such as iodoacetic acid. The mechanism involved may be similar to that suggested for the inhibition of some serine proteolytic enzymes from yeast (Bai \& Hayashi, 1979; Kominami et al., 1981) in which binding of the mercurials prevents access of substrates to the active site. Considering all the inhibitor data it would appear that proteinase $\mathrm{E}$ is probably a pepstatininsensitive aspartic proteinase. Examples of these have been reported in other eukaryotic microorganisms (North, 1982a).

A comparison of the physical properties of proteinase $E$ with those of similar fungal enzymes shows that its apparent molecular weight of 58000 was above the range of 30000 to 45000 into which most fungal acid proteinases fall (North, 1982a). Mammalian cathepsin D also has a lower molecular weight of about 42000 (Barrett \& McDonald, 1980). Proteinase E was presumably a glycoprotein and it is possible that the presence of a larger carbohydrate moiety may be responsible for the higher molecular weight. Variations in the carbohydrate content could be responsible for the heterogeneity revealed by isoelectric focusing (Fig. 2). The isoelectric points of all forms of proteinase $\mathrm{E}$ showed that it was more acidic than most acid proteinases from fungi (North, 1982a) and cathepsin D (Barrett \& McDonald, 1980).

Whilst proteinase $E$ showed properties similar to fungal acid proteinases, proteinase $B$ represented a type of proteinase common to many protozoan species but very much less frequently encountered amongst the fungi (North, 1982a). A number of properties indicated that it was a cysteine proteinase. Its activity was enhanced by DTT, it was inactivated by a range of typical cysteine proteinase inhibitors and was active on a range of synthetic substrates with a basic amino acid at the $P_{1}$ position. Since Bz-Pro-Phe-Arg-Nan and Bz-Phe-Val-Arg-Nan were the best of the peptide nitroanilide substrates a bulky amino acid residue at the $\mathrm{P}_{2}$ position was clearly preferred. The additional activity revealed with Bz-Val-Gly-Arg-Nan as substrate when aminopeptidase $M$ was added to the assay system requires explanation. The presence of this activity in cell extracts had already been deduced (North, 1982b). The most likely basis for this activity is that proteinase B split the substrate internally, possibly at the Gly-Arg bond with the 
bulky valyl residue at the $\mathrm{P}_{2}$ position, and then aminopeptidase $\mathrm{M}$ split the Arg-Nan bond releasing nitroaniline.

A comparison of the properties of proteinase B with those of the three cysteine proteinases of mammalian cells, cathepsins B, H and L (Barrett \& Kirschke, 1981) suggests that it most closely resembles cathepsin B. Unlike cathepsin H [BANA (Bz-Arg-NNap) hydrolase], proteinase B had no aminopeptidase activity and was inhibited by leupeptin. Unlike cathepsin L, a highly active proteinase which also hydrolyses $\mathrm{Cbz}-\mathrm{Lys}-\mathrm{ONp}$, proteinase $\mathrm{B}$ was active on Bz-ArgNNap and was inhibited by 3 M-urea (M. J. North, unpublished observation). However there were some differences from cathepsin B. Proteinase B was not completely inactivated at high $\mathrm{pH}$ values and this allowed it to be detected after electrophoresis at $\mathrm{pH} 8.9$ on haemoglobin gels. It was also larger and more acidic than cathepsin B which has a molecular weight of about 25000 and an isoelectric point of pH 4.5 to 5.5 (Barrett \& McDonald, 1980).

Like proteinase B, proteinase I from $D$. discoideum hydrolyses Cbz-Lys-ONp at $\mathrm{pH} 6$ and a number of proteins at lower $\mathrm{pH}$ values (Gustafson \& Thon, 1979). Although the specific activity of purified proteinase $B$ on Cbz-Lys-ONp was lower than that of proteinase $I$ [13.1 and $34.0 \mu \mathrm{mol}$ nitrophenol released $\mathrm{min}^{-1}(\mathrm{mg} \text { protein })^{-1}$, respectively] there were a number of similarities which suggest that they could be the same enzyme. Proteinase B was an acidic glycoprotein which is consistent with the presence of sugar phosphoryl moieties in proteinase I (Gustafson \& Milner, 1980). Although preparations of proteinase B normally contained only one polypeptide and proteinase I was reported to consist of three non-identical subunits, the occasional appearance of two minor smaller polypeptides in proteinase B preparations suggests that the smaller subunits of proteinase I, which had similar molecular weights to these polypeptides, might have been produced by autolysis. The largest subunit of proteinase I had a molecular weight of 34500 (Gustafson \& Thon, 1979), similar to that of proteinase B. However, since multiple forms of cysteine proteinases have been detected in $D$. discoideum (North \& Harwood, 1979) a more detailed comparison between the proteinases will be necessary before it can be concluded that they are identical.

The results on substrate specificity obtained with the purified preparations of both proteinases can be compared with the previous results from cell extracts (North, 1982 $b$ ). Activity on the substrates hydrolysed by the proteinases is found predominantly in the lysosomal fraction $(15000 \mathrm{~g}$ pellet). However, whilst activity associated with proteinase E (HPA hydrolysis) is present throughout the life cycle of $D$. discoideum, those associated with proteinase B decrease during fruiting body formation, an observation also reported by other workers (Gustafson \& Thon, 1979; Fong \& Rutherford, 1978). Recent observations on proteolytic enzymes during spore germination have revealed little change in proteinase $E$ activity but there is increased cysteine proteinase activity during the emergence phase (North \& Cotter, 1983). Although their physiological function is not known for certain it would seem likely, in view of their operational $\mathrm{pH}$ range and the subcellular localization, that both proteinases are general digestive enzymes. The difference in developmental control might be a reflection of a more predominant role for proteinase B during growth. It is likely that proteolytic processes may not be uniquely dependent on the action of one proteinase and that in vivo either proteinase may work in concert with other proteolytic enzymes. An understanding of their properties may help to distinguish their contributions to such processes and help to elucidate the mechanisms involved in the control of their activity in civo.

We wish to thank Marion Walker for assistance with some of the experiments. This work was supported by a grant from the Science and Engineering Research Council.

\section{REFERENCES}

Ansari, H. \& Stevens, L. (1983). Purification and properties of two neutral proteinases from Aspergillus nidulans. Journal of General Microbiology 129, 16371644.

Bai, Y. \& Hayashi, R. (1979). Properties of the single sulfydryl group of carboxypeptidase Y. Effects of alkyl and aromatic mercurials toward various synthetic substrates. Journal of Biological Chemistry 254, 8473-8479.

BARRETT, A. J. (1972). A new assay for cathepsin B1 
and other thiol proteinases. Analytical Biochemistry 47, 280-293.

Barrett, A. J. (1973). Human cathepsin B1. Purification and some properties of the enzyme. Biochemical Journal 131, 809-822.

BARRETT, A. J. (1977) Introduction to the history and classification of tissue proteinases. In Proteinases in Mammalian Cells and Tissues, pp. 1-55. Edited by A. J. Barrett. Amsterdam: Elsevier/North-Holland Biomedical Press.

BarRetT, A. J. \& KirSchke, H. (1981). Cathepsin B, catbepsin H, and cathepsin L. Methods in Enzymo$\log y$ 80, 535-561.

BarreTt, A. J. \& McDonald, J. K. (1980). Mammalian Proteases: A Glossary and Bibliography. Volume I Endopeptidases. London: Academic Press.

Braun, V., Hantke, K., Wolff, H. \& Gerisch, G. (1972). Degradation of the murein lipoprotein complex of Escherichia coli cell walls by Dictyostelium discoideum amoebae. European Journal of Biochemistry 27, 116-125.

Coukell, M. B. \& Walker, I. O. (1973). The basic nuclear proteins of the cellular slime mold Dictyostelium discoideum. Cell Differentiation 2, 87-95.

FirTel, R. A. \& Brackenbury, R. W. (1972). Partial characterization of several protein and amino acid metabolizing enzymes in the cellular slime mold Dictyostelium discoideum. Developmental Biology 27, 307-321.

Fong, D. \& Bonner, J. T. (1979). Proteases in cellular slime mold development: evidence for their involvement. Proceedings of the National Academy of Sciences of the United States of America 76, 64816485.

Fong, D. \& Rutherford, C. L. (1978). Protease activity during cell differentiation of the cellular slime mold Dictyostelium discoideum. Journal of Bacteriology 134, 521-527.

Gustafson, G. L. \& Milner, L. A. (1980). Occurrence of $\mathrm{N}$-acetylglucosamine-1-phosphate in proteinase I from Dictyostelium discoideum. Journal of Biological Chemistry 255, 7208-7210.

Gustafson, G. L. \& Thon, L. A. (1979). Purification and characterization of a proteinase from Dictyostelium discoideum. Journal of Biological Chemistry 254, 12471-12478.

Holzer, H. \& Heinrich, P. C. (1980). Control of proteolysis. Annual Review of Biochemistry 49, 63-91.

Kominami, E., Hoffschulte, H. \& Holzer, H. (1981). Purification and properties of proteinase $\mathbf{B}$ from yeast. Biochimica et biophysica acta 661, 124-135.

Kost, R. G., North, M. J. \& Whyte, A. (1981). Acid proteinases in various species of cellular slime mold. Experimental Mycology 5, 269-277.

LAH, T. \& TURK, V. (1982). Autolysis studies of cathepsin D. Hoppe-Seyler's Zeitschrift für physiologische Chemie 363, 247-254.

Leichtling, B. H., Majerfeld, I. H., Coffman, D. S. \& RiCKenBerG, H. V. (1982). Identification of the regulatory subunit of a cAMP-dependent protein kinase in Dictyostelium discoideum. Biochemical and Biophysical Research Communications 105, 949-955.
NoRTH, M. J. (1978). Inhibition of acid proteinase from Dictyostelium discoideum. Biochemical Society Transactions 6, 400-403.

NORTH, M. J. (1982a). Comparative biochemistry of the proteinases of eucaryotic microorganisms. Microbiological Reviews 46, 308-340.

North, M. J. (1982b). Proteolytic activities in Dictyostelium discoideum detected with chromogenic peptide substrates. Experimental Mycology 6, 345-352.

NORTh, M. J. \& CotTer, D. A. (1983). Proteolytic enzyme activity during Dictyostelium discoideum spore germination. Experimental Mycology (in the Press).

NORTH, M. J. \& HARWOOD, J. M. (1979). Multiple acid proteinases in the cellular slime mould Dictyostelium discoideum. Biochimica et biophysica acta 566, 222233.

North, M. J. \& Whyte, A. (1981). Purification of proteinase E from Dictyostelium discoideum. Society for General Microbiology Quarterly 8, 273.

North, M. J., Whyte, A. \& Ventom, A. (1982). Chloroquine effects in Dictyostelium discoideum: inhibition of other enzymes besides the cathepsin B. FEMS Microbiology Letters 15, 189-192.

Rossomando, E. F., Maldonado, B., Crean, E. V. \& Kollar, E. J. (1978). Protease secretion during onset of development in Dictyostelium discoideum. Journal of Cell Science 30, 305-318.

SCHECHTER, I. \& Berger, A. (1967). On the size of the active site in proteases. I. Papain. Biochemical and Biophysical Research Communications 27, 157-162.

Sedmak, J. J. \& GrossberG, S. E. (1977). A rapid, sensitive and versatile assay for protein using Coomassie brilliant blue G250. Analytical Biochemistry 79, 544-552.

SMITH, R. \& TURK, V. (1974). Cathepsin D: rapid isolation by affinity chromatography on haemoglobin-agarose resin. European Journal of Biochemistry 48, 245-254.

Sussman, M. \& Sussman, R. (1969). Patterns of RNA synthesis and of enzyme accumulation and disappearance during cellular slime mould cytodifferentiation. Symposium of the Society for General Microbiology 19, 403-435.

WATTS, D. J. \& Ashworth, J. M. (1970). Growth of myxamoebae of the cellular slime mould Dictyostelium discoideum in axenic culture. Biochemical Journal 119, 171-174.

Weber, K., Pringle, J. R. \& Osborn, M. (1972). Measurement of molecular weights by electrophoresis on SDS-acrylamide gel. Methods in Enzymo$\log y$ 26, 3-27.

WIENER, E. \& Ashworth, J. M. (1970). The isolation and characterization of lysosomal particles from myxamoebae of the cellular slime mould Dictyostelium discoideum. Biochemical Journal 118, 505-512.

Winter, A., EK, K. \& ANDERsSON, U.-B. (1977). Analytical electrofocussing in thin layers of polyacrylamide gels. LKB Application Note 250.

Zacharius, R. M., Zell, T. E., Morrison, J. H. \& WoODLOCK, J. J. (1969). Glycoprotein staining following electrophoresis on acrylamide gels. Analytical Biochemistry 31, 148-152 